by Anil Kumar ${ }^{1}$, Yogesh Ray², Rupa Ghosh ${ }^{1}$, Sujay Bandyopadhyay ${ }^{3}$, Vimal Singh ${ }^{4}$, Pradeep Srivastava ${ }^{*}$

\title{
Late Quaternary sedimentation history of the Himalaya and its foreland
}

\author{
${ }^{1}$ Wadia Institute of Himalayan Geology, 33 GMS Road, Dehradun 248 001, Uttarakhand, India \\ ${ }^{2}$ National Centre for Polar and Ocean Research, Headland Sada, Vasco da Gama-403 804, Goa, India \\ ${ }^{3}$ Department of Geography, Kazi Nazrul University, Asansol 713 340, Paschim Barddhaman, West Bengal, India \\ ${ }^{4}$ Department of Geology, Chhatra Marg, University of Delhi, Delhi - 110007, India \\ *Correspondence,Email: pradeep@wihg.res.in
}

(Received : 20/01/2019; Revised accepted : 7/08/2019)

https://doi.org/10.18814/epiiugs/2020/020032

Himalaya and its foreland acted as a coupled system that responded to the climate variability and evolved as a thrust and fold belt. The river systems draining the Himalaya, the Ganga foreland act as an artery that helps registering climate and tectonic signals into its geomorphology and sedimentary history. The paper discusses the late Quaternary landscape evolution of the mountain and its foreland and reviews the published literature in the context. It mainly focusses on the alluvial landscape and compiles the chronological data to decipher the evolution of mountain, the Ganga foreland and the delta. The review suggests that rivers in Himalaya largely aggraded during the climatic transition between the dry glacial and wet interglacial. The incision of the river valleys took place during peak of the warm interglacial periods when Indian Summer Monsoon strengthened. The Ganga plain rivers exhibit varied geomorphology that depended on the proximity to the mountain, forebulge of the foreland and type of drainage (transverse or axial). The rivers in the west are incised while those in the east are shallow and avulsive. The sedimentary history of the Ganga plain implies being forced from $\mathrm{N}$-S movement of monsoon front and foreland dynamics over the past $120 \mathrm{ka}$. The delta region of Ganga has been responding to the fluctuating sea level and delta progradation (retro-gradation).

\section{Introduction}

The Himalaya and its foreland were formed due to collision of the Indian and Asian plates and the subsequent crustal shortening
(Molnar, 1984). Soon after the collision, a forearc basin was formed at the leading edge of the Indian Plate where molassic sedimentation took place from Oligocene to early Miocene (Parkash et al., 1980, Burbank et. al., 1996a). These sediments are called as Indus molasse; the fossil record suggests that the elevation of the basin was $\sim 600 \mathrm{~m}$ above the sea level (asl) (Paul et al., 2007). The ongoing northward push of the Indian Plate led to a southward progressive deformation and formation of Himalayan fold and thrust belt that now touches a maximum elevation of $>8.5 \mathrm{~km}$. The thrust sheet loading in Himalaya later led to the formation of a peripheral foreland basin that extends E-W parallel to the Himalayan ranges. The Himalayan mountain (or the northern hinterland), the craton (or the southern hinterland), the Himalayan foreland, and the Indus and Ganga-Brahmaputra deltas are the major geomorphic domains.

During summer, differential heating of the elevated HimalayaTibet landmass develops a low-pressure zone which creates the necessary pressure gradient to drive the Indian Summer Monsoon (ISM). This relationship is known to exist since $\sim 10 \mathrm{Ma}$. It is the orographic structure of the Himalaya that decides the pattern of rainfall distribution for a large part of the Indian sub-continent. The southern Himalayan front receives full spectrum $(100 \mathrm{~mm} / \mathrm{a}$ in the NW and $\sim 3500 \mathrm{~mm} / \mathrm{a}$ in the NE) of the ISM rainfall, whereas the northern part of the Himalaya remains a rain shadow zone of the ISM. Therefore, the interaction between the precipitation-driven climatic perturbations, surface processes and the geology of the Himalaya result in varied landscapes. The river valleys that drain the Himalaya, deliver a large volume of sediments to intermittent depocenters along its course (such as wide valleys, the dun or intermontane valleys, and the Indo-Gangetic-Bramhaputra plains) and eventually to their ultimate sinks, viz., the Bay of Bengal and the Arabian Sea. The sediment load, tectonics, ISM, and eustatic sea-level changes govern the zones of deposition and river erosion/incision in the continuum of the Himalaya-Ganga-Brahmaputra Foreland-Delta system.

In the last decade, several researches focused on the understanding of the Himalayan river response to the tectonic and climatic changes (Bookhagen et al., 2006; Hodges et al., 2004; Kumar et al., 2007, Srivastava et al., 2008, 2009; Ray and Srivastava, 2010; Dutta et al., 
2012; Kumar and Srivastava, 2017). As a result 75 ka climatetectonic history of the Indus, the Brahmaputra, the Ganga and their tributaries has been developed. Studies were also carried out on Gangetic Plains and deltaic regions to understand the timing and style of aggradation and degradation in response to the foreland dynamics, climate, and sea-level changes (e.g., Goodbred and Kuehl, 2000a; Jain and Tandon, 2003; Srivastava et al., 2003a; Ghosh et al., 2019). This contribution aims to review the important findings of studies undertaken in the last decade on different geomorphic domains of the Himalayan system. We provide a synoptic view of (i) timings of aggradation-incision and, (ii) roles of tectonics, climate, and sea-level changes in shaping the modern landscape of the Himalayan terrain. The studies dealing with the late Quaternary geomorphology, sedimentology, and geochronology of the fluvial sequences of the Himalayan system have been considered in this review.

\section{Geology, structure and Climate}

The modern structure of Himalaya has evolved due to continued compression via crustal shortening and thrust sheet loading (Yin and Harrison, 2000; Fig.1). Its southernmost thrust, referred to as the Himalayan Frontal Thrust (HFT), brings the Siwalik Group of rocks (relict foreland mid-Miocene to lower Pleistocene) over the modern alluvium of the Ganga Foreland. The Siwalik rocks are themselves thrusted over by meta-sedimentaries of the Lesser Himalayan affinity along the Main Boundary Thrust (MBT). The Lesser Himalayan meta- sediments are thrusted over by the Higher Himalayan Crystallines (HHCs) along the Main Central Thrust (MCT). Further, the Tethyan sediments are separated from the HHCs by a normal fault referred to as the South Tibetan Detachment System (STDS). The Tethyan sediments overlie the Zanskar Shelf sediments along the north-vergent Zanskar Counter Thrust. Further, in the north the Indus molasse sedimentsare separated from the Zanskar Shelf sediments by the Choksti thrust and from the Ladakh Batholith by the Upshi-Bazgo Thrust. The Himalayan part lying south of the STDS is referred here as the wet southern Himalayan front as it receives rainfall as high as $2500 \mathrm{~mm} / \mathrm{a}$. The region to the north of the STDS, here referred to as the arid northern Himalayan front, remains under the rain shadow of the ISM and more dominantly receives precipitation by westerlies (500-100 mm/a). From east to west and from south to north along the mountain, the intensity of the ISM decreases. The main Himalayan Rivers - the Ganga and Brahmaputra drain through the southern front, while the Indus, the Spiti and the Zanskar drain the dry northern parts. Figure 1 provides a broad overview of the study area.

\section{Late Quaternary evolution of the geomorphic domains}

The salient features of (i) the northern hinterland, (ii) the southern hinterland, (iii) the Himalayan foreland, and (iv) the deltas are discussed separately. Further, the Himalayan rivers are tentatively

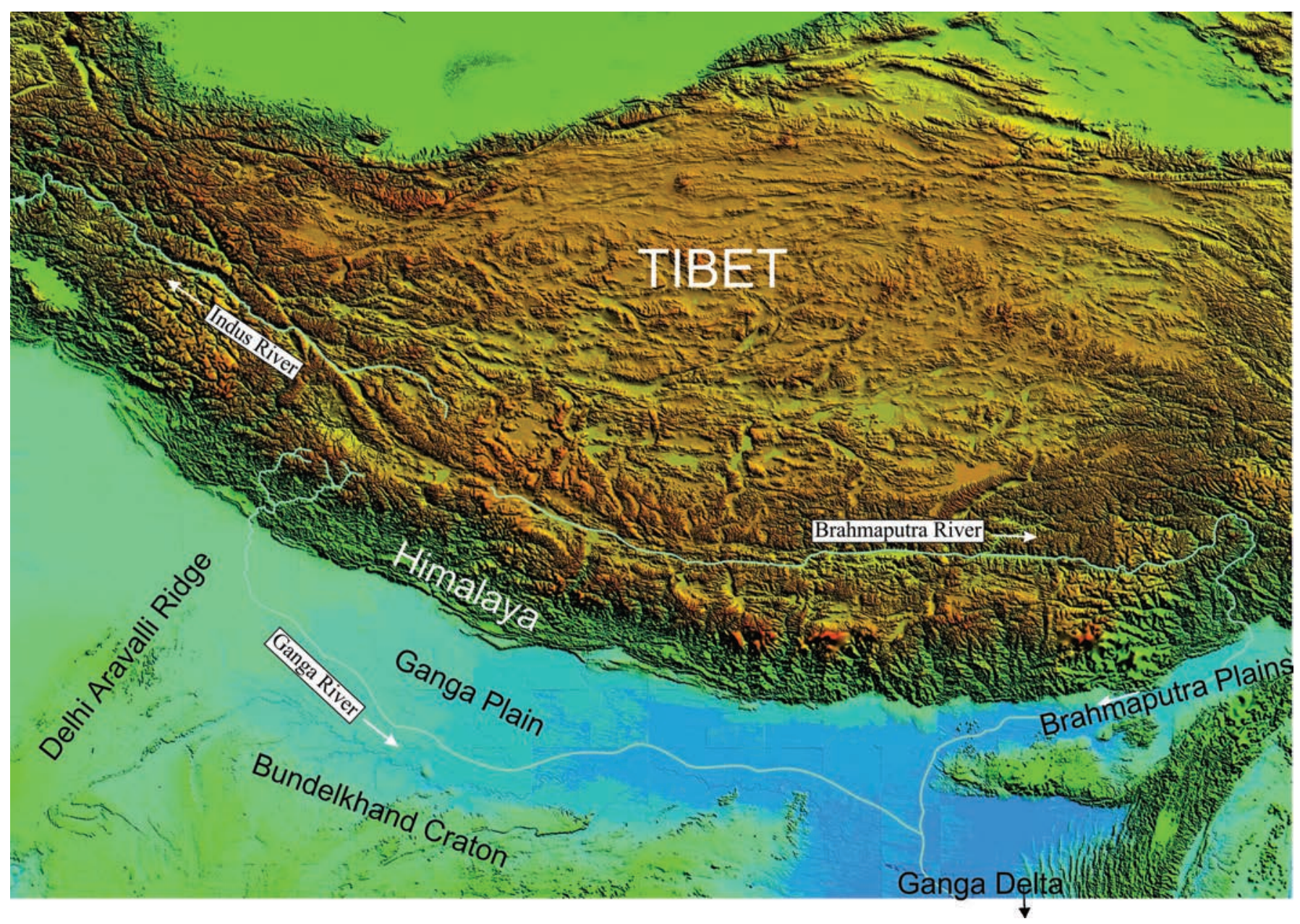

Figure 1. Overview of study area showing the Himalaya, the Ganga-Brahmaputra Foreland and location of Deltaic region. 
divided into (a) the rivers draining the lee-ward side of the Himalaya (northern part of the Himalaya), and (b) the rivers draining the windward side of the Himalaya (southern part of the Himalaya).

\section{Sedimentation in the northern hinterland}

The sedimentation style and aggradation in rivers of this part of the Himalaya depend upon two major factors: (i) water and availability of sediment in the drainage network, and (ii) precipitation pattern (Bookhagen and Burbank, 2010). While the ISM, groundwater, and glacial/snowmelt are the main sources of water, the sediment-supply to the channels is by the glacial and hillslope erosion and masswasting. These factors, i.e., sediment and water, vary in space and time. The surface processes like normal and extreme floods, debris flows, and channel damming and lake formation are common that produce excess sediment supply resulting in valley-filling. The channel aggrades during higher sediment to water ratio and incises during the peak ISM phases (Blum and Törnqvist, 2000; Ray and Srivastava, 2010; Kumar and Srivastava, 2017). Therefore, the fill sequences in the river valleys normally comprise (i) fining upward imbricated gravels implying aggradation on channel bar during normal monsoon floods, (ii) mud-supported fining upward beds of angular to subangular gravels that signify deposits of the past extreme floods and events of cloud bursts, (iii) the poorly-sorted mud-supported gravels often occur as indications of the past landslides, and (iv) fine-grained clayey silt deposits indicating formation of dammed lakes, often a result of interaction of landslides, fans and channels. The processes like glacial lake outburst floods (GLOFs) are often represented by debris flows and thick piles of poorly-sorted sand (Juyal et al., 2010; Chaudhary et al., 2015; Sharma et al., 2016; Srivastava et al., 2017).

Arid northwestern (NW) Himalaya: Most valleys of the NW Himalaya exhibit valley filling by channel and fan-bound processes that helped to aggrade the valley and led to formation of fill terraces. The catchment basins of relatively drier Himalaya are associated with two precipitation systems: (i) The ISM that fetches moisture from the Arabian Sea and Bay of Bengal and brings rainfall to southern front of the Himalaya during summer months (June-September); but during abnormal monsoon years it results in heavy rainfall in the dry areas (Bookhagen et al., 2005). The ISM is responsible for $<50 \%$ of the hydrological budget of the Himalayan Rivers (Bookhagen and Burbank, 2010). (ii) The second system is driven by the mid-latitude westerlies that precipitate in the form of snow during winter months adding $>50 \%$ to the hydrological budget (Bookhagen and Burbank, 2010). During the warmer phases enhanced landslide activity and hillslope erosion mobilize large volume of sediments in the trunk channel that leads to valley aggradation (Bookhagen et al., 2005; Korup et al., 2007; Dortch et al., 2009; Juyal et al., 2010; Ray and Srivastava, 2010; Srivastava et al., 2013).

Several studies in the Indus, Zanskar and Baspa river valleys, NW hinterland Himalaya have been carried out on the valley fills, outwash fans, and debris flows, suggested various aggradation and incision periods in the valleys (Shukla et al., 2002; Pant et al., 2005; Phartiyal et al., 2005; Dortch et al., 2010; Nag and Phartiyal, 2015; Kumar and Srivastava, 2017; Dutta et al., 2018; Lal et al., 2019. Kumar and Srivastava (2017) suggested aggradation in three pulses centred at $\sim 52, \sim 28$ and $\sim 16$ ka and showed that the fan building processes started at $\sim 47 \mathrm{ka}$ and debris flows centred at $\sim 27 \mathrm{ka}$. Another study from the Indus and its tributary Zanskar River, suggested valley filling in two phases at 200 and during 50-20 ka (Blöthe et al., 2014). Recent studies, including those on chronology, sedimentary architecture and provenance of the valley fill from the Zanskar using fluvial terraces, fan and lake deposits suggested that the river aggraded at 32-25 ka and 8-6 ka (Jonell et al., 2018; Chahal et al., 2019). The valley-fill sequences along the Tangste River (Trans-Himalaya) show two phases of aggradation at 48 and 30-21 ka (Phartiyal et al., 2015). Further, a study establishing the chronology of the paleolake deposits along the Indus River suggested three phases of lake formation during warm and wet climate at 35-26 ka (Lamayuru palaeolake); 17-13 ka (Rizong palaeolake), and 14-5 ka (KhalsiSaspol palaeolake) (Nag and Phartiyal, 2015; Nag et al., 2016). Episodic filling in the valley was caused by glaciogenic, fluvial, lacustrine, and alluvial sedimentation during intensified monsoon periods (Phartiyal et al., 2015). The Spiti River valley, in the similar climatic domain of the NW Himalaya, also experienced two phases of fluvial aggradation during the wet phases of 50-30 ka (MIS-3) and 14-8 ka (MIS-1) (Phartiyal et al., 2009a; Srivastava et al., 2013); these phases are related to lake formations due to damming of the river (Phartiyal et al., 2009 a, b). Similar studies from the Baspa River valley suggested alluvial fan progradation at $\sim 45 \mathrm{ka}$ under warm and humid deglacial phase, and during the MIS-3 (>23 ka) strengthened precipitation-induced large landslides blocking the river course and formation of lakes that recorded sedimentation until the early Holocene (Dutta et al., 2018).

Semi-arid NW Himalaya: Includes the monsoon dominated Satluj valley which experienced three discreet phases of valley filling between 13 and $0.4 \mathrm{ka}$. Two levels of valley-fill fluvial sediments in the Satluj valley have sandwiched the deposits of alluvial and debris flow indicating episodes of high magnitude floods during the postglacial transitional climate (Sharma et al., 2016). Meanwhile, rivers in the northern Tibet in Kunlun Mountains are known to have built large fans during the MIS-3 (Owen et al., 2006). Likewise, two phases of rainfall-induced landslides are also reported in the catchments of the NW Himalaya: MIS-3 and MIS-1 (Dortch et al., 2009; Srivastava et al., 2013).

The strath terraces - geomorphic manifestation of the past river beds, are used to reconstruct paleo-riverbed profile and decipher the style of neotectonic responses. In Nanga Parbat-Haramosh Massif (NPHM) of the NW syntaxis, two levels of strath terraces along the Indus are dated $\sim 7 \mathrm{ka}$ and between 67 and $27 \mathrm{ka}$ (based on ${ }^{10} \mathrm{Be}$ and ${ }^{26} \mathrm{Al}$ cosmogenic radionuclides); the inferred bedrock incision rates from these dates are as high as 9-12 mm/a during the Holocene, and 1-6 mm/a during the pre-LGM (Burbank et al., 1996b; Leland et al., 1998). Modern incision rate of the Indus in the NPHM is $12 \mathrm{~mm} / \mathrm{a}$, which reduces to 3-6 mm/a, around $50 \mathrm{~km}$ upstream at Skardu. PostLGM incision rates of Baraldu River that meets the Indus near Skardu are computed to be $2-29 \mathrm{~mm} / \mathrm{a}$ (Seong et al., 2008). The studies on strath terraces along the Indus in the Indian part suggest incision during 44-65 ka at the rate of 1-2.2 mm/a (Kumar and Srivastava, 2017). A gradual increase in the incision rates from $1-3 \mathrm{~mm} / \mathrm{a}$ at Leh to $12 \mathrm{~mm} / \mathrm{a}$ in the NHPM implies tectonics along the NW Syntaxis, which lead to rapid fall in the base level. This introduced the incision in the upper Indus (Kumar and Srivastava, 2017). Lal et al. (2019) provided a framework of tectonic instability and reorganization of drainage in the Indus River basin by studying the mineral assemblages 
of 73 ka old section comprising paleolake, fan, and fluvial deposits along the basin. Switching of sediment source is suggested based on the medium grade metapelites mineral assemblage (staurolite, kyanite and garnet) from Pangong Tso Crystalline complex. Nonetheless, this mineral assemblage is also reported in the Indus River catchment, i.e., Tso Moriri Crystalline (De Sigoyer et al., 2004).

More recently, the fluvial terrace and geomorphic investigation along the Indus in Leh valley indicated a neotectonic deformation in the Indus Molasse and shortening of $\sim 10 \mathrm{~m}$ along the Stok Thrust since $\sim 42$ ka (Sinclair et al., 2017). Further, the Tangtse River in the Trans-Himalaya, flowing along the strands of the Karakoram Fault, shows evidence of neotectonic activity along the Karakoram Fault (e.g., Jain and Singh, 2008). Phases of river incision during 22-5.1 ka and geomorphologic features such as fan-into-fan topography indicated that the basin is neotectonically active (Phartiyal et al., 2015). In the Spiti valley, fluvial fill sequences exhibit soft-sediment deformation structures that are dated between 90 and $26 \mathrm{ka}$ and further 50-30 ka old paleolake sequences are mapped perched up on strath terraces suggesting the late Pleistocene tectonic deformation along the Kaurik-Chango fault (Singh and Jain, 2007; Phartiyal et al., 2009a). Tectonic activity during the early-mid Holocene in the Spiti valley is identified from the study of landslide-dammed paleolakes; these deformed sediments yield the age between 7.8 and $6.1 \mathrm{ka}$ at Mane paleolake deposits (Anoop et al., 2012).

Sedimentation in the southern Himalayan Front: Some segments of the major river valleys in the Himalaya have thick fluvial deposits in the form of cut-and-fill terraces. The cut-and-fill terraces are formed when the rivers cut their own deposits. In general, such segments are relatively wider reaches of rivers where sufficient space to accommodate the sediments exists. Local geomorphic processes such as landslides, hillslope processes, and tributaries play an important role in the filling of such reaches (Devrani and Singh, 2014). Investigations in the Ganga river system have demonstrated that widespread valley-scale aggradation is strongly controlled by the climatic shifts (Juyal et al., 2010; Ray and Srivastava, 2010). Terraces also develop in response to tectonic activities; these terraces are generally strath terraces developed by the planation of bedrock. The generation of cut-and-fill terraces, as studied along the Alaknanda, Ramganga, Tista and Brahmaputra Rivers, can develop in response to the tectonic activity, but irrespective of the mechanism these are formed in the late Pleistocene-Holocene sediments that have a strong climatic control (Meetei et al., 2007; Srivastava and Misra, 2008; Srivastava et al., 2008; Juyal et al., 2010; Ray and Srivastava, 2010; Scherler et al., 2014; Dey et al., 2016). The deposition in the valleys shows cyclic phases of aggradation and incision. Thesouthern Himalayan front responds to changes in precipitation overwhelmingly and sediment generation takes place both via physical and chemical weathering(Dosseto and Vigier, 2015). The extreme hydrological events that are more common and that ride over phases of strengthened monsoon(Singh, 2014; Devrani et al., 2015; Das et al., 2015; Sundriyal et al., 2015; Srivastava et al., 2017) help in mobilizing huge amounts of sediment from the paraglacial regions into the low-gradient lower valley segments (Ray et al., 2011)

Foothills and Intermontane valleys: In the foothills of the Himalaya, alluvial fans, coalescing fans (piedmont), terraces, and duns (intermontane valleys) are the major landforms (Kumar and Sangode, 2007; Suresh et al., 2007; Thakur et al., 2007; Singh and Tandon,
2008, 2010; Chakraborty and Ghosh, 2010; Chakraborty et al., 2010; Goswami and Mishra, 2013; Pandey et al., 2014; Tandon and Singh, 2014; Abrahami et al., 2018). On the basis of Optically Stimulated Luminescence (OSL) dates in Pinjaur/Son Dun, Suresh et al. (2007) suggested that the beginning of fan building activity initiated at $~ 90$ ka. They further suggested that the climatic condition during this period was suitable as it facilitated mobilization of large volume of sediments from the relatively higher mountains and significant volume from it got trapped in the alluvial fans at the foothills of the Himalaya. However, the fan building process is also controlled by the tectonic activity as indicated by the tilting of such fans (Singh and Tandon, 2007). Further, through paleoseismological and geomorphic investigations, it is also well established that the Main Frontal Thrust (MFT)/Himalayan Frontal Thrust (HFT) is the most active structure in the Himalaya since the late Quaternary (Wesnousky et al., 1999; Lave and Avouac, 2000; Kumar et al., 2001; Thakur, 2013). In the NW sub-Himalaya the sedimentation isshown to be in-phase with the climatic shifts (Dutta et al., 2012; Pandey et al., 2014).

In the eastern sector of the Himalaya, the Tista fan evolved as the river avulsed during 45-12 ka. The incision of fan is suggested to be governed by mountain front tectonics (Chakraborty et al., 2010; Singh et al., 2017). In the Arunachal Himalaya, the sedimentation and river incision along the Brahmaputra River, is suggested as an intricate interplay of tectonics along the HFT and the climatic variations during 15-8 ka. In the upstream regions, river incised into bedrock and formed four levels of terraces at Tuting between 25 and 8 ka (Srivastava and Misra, 2008, 2012; Srivastava et al., 2009)

\section{Sedimentation in the Himalayan Foreland/Ganga Plains}

The Himalayan foreland basin, south of the Himalaya, developed due to down-flexing of the Indian lithosphere in response to thrust sheet loading (Singh, 1996; Agarwal et al. 2002; Ghosh et al., 2019). The sedimentation in this basin occurred via Himalayan and cratonic rivers, which is still continuing (Rahaman et al., 2009; Tripathi et al., 2013). The basin is called as the Indo-Ganga-Brahmaputra plains and exhibit a variety of geomorphological units and landforms,viz., piedmont fans (PF), megafans (MF), raised interfluves, marginal plains, river terraces, floodplains and active channels (Singh, 1996; Srivastava et al., 2003a). Development of these represent the interplay of climate and tectonics, both in the Himalaya and its foreland (Singh and Tandon, 2008, 2010). The rivers in the western Ganga Plain have relatively high stream power than those in the eastern Ganga Plain; therefore, they show the development of incised valleys and raised interfluves (Bawa et al., 2014). On the other hand, the rivers in the eastern Ganga Plains due to low stream power and high sediment to water ratio tend to be avulsive and give rise to the landforms like alluvial fans. For example, the Kosi River makes a mega-fan after exiting the Himalaya (Jain and Sinha, 2004; Sinha et al., 2005, 2008, 2014). Recently, Dingle et al. (2016) demonstrated the role of longterm tectonics on the variation in river forms of the eastern and the western Himalayan Rivers. They showed that the variation in the rate of subduction along the Himalayan front also imparts a control on the geomorphic variability in the Ganga basin. The cliff sections exposed along the incised rivers of the Ganga Plain reveal the sedimentation history of the past 100 ka (Singh, 1996; Singh et al., 1997; Shukla et al., 2001; Srivastava et al., 2003b; Gibling et al., 
2005; Sinha et al., 2007; Shukla, 2009; Srivastava et al., 2010, 2018; Pal et al., 2012; Roy et al., 2012; Shukla et al., 2012; Ghosh et al., 2019). The rivers of the eastern Ganga plains highlight the role of the channel avulsion and floods, in the distribution of sediments in the plains (Singh and Awasthi, 2011; Sinha et al., 2014). We summarize the findings of the literature, from the western, central, and the eastern Ganga Plains.

The outcrops along the Ganga River in the central Ganga Plain provide a 100 ka history, where the upper $13 \mathrm{~m}$ section at Bithur, in the central Ganga Plain, yielded OSL ages of $51 \pm 5 \mathrm{ka}, 17 \pm 4 \mathrm{ka}$ and 13 \pm 2 ka (Srivastava et al., 2003a,b; Gibling et al., 2005; Sinha et al., 2007). Similarly, a drilled core in the vicinity of Indian Institute of Technology, Kanpur(IIT-K) suggested $\sim 50 \mathrm{~m}$ aggradation in the Yamuna-Ganga interfluve, between $86 \pm 7$ ka and the late Holocene. The isotopic provenance indicators in the IIT-K core suggested century/millennium scale, climate-controlled coupling between Himalaya and the depocenter (Rahaman et al., 2009); however there also exist diverse views on this (Agarwal et al., 2013; Tripathi et al., 2013). Further south (in and around Kalpi), in the sections along the Yamuna River and its tributaries, sedimentological details and faunal assemblage indicated a warm wet climate during the Marine Isotope Stage-3 (MIS-3), and where $25 \mathrm{~m}$ thick aggradation took place in $\sim 100$ ka (Tewari et al., 2002; Srivastava et al., 2003b; Gibling et al., 2005; Sinha et al., 2009; Srivastava and Shukla, 2009; Agrawal et al., 2013; Tripathi et al., 2013; Ghosh et al., 2019). The sequences in the region are normally divided into three depositional unitsand the ages of the bottom and the top most units of the Yamuna River section at Kalpi is $119 \pm 12 \mathrm{ka}$ and $32 \pm 5 \mathrm{ka}$, respectively (Gibling et al., 2005; Sinha et al., 2007). Lateral facies architecture and regional correlation of depositional units in the Ganga Plain suggest wetter climate-driven active aggradation between $>90$ and $25 \mathrm{ka}$, and formation of nondepositional discontinuity surfaces during the drier LGM (Gibling et al., 2005). The lower unit (>100 ka) forms a regional horizon of moderately developed paleosols, which is overlain by lensoidal units of craton-derived channelized gravel followed by a package of Himalaya-sourced sediments. The gravel unit yields a mammal assemblage indicative of warm and wet climate and suggests basinward progradation of gravely alluvial fans from the peripheral region of the foreland implying tectonic uplift in the forebulge of the Ganga foreland (Ghosh et al., 2019). The fossil assemblage comprises the largest Asiatic elephant tusk, shoulder blade of elephant, molars of Equus, Bovids, Bos, and Elephus cf. namadicus, etc. (Singh et al., 1997; Verma et al., 1998; Tewari et al., 2002; Ghosh et al., 2016).

Recently, micromorphological studies in various sections of the Ganga-Yamuna interfluve identified regionally correlated, moderately developed paleosol surfaces occurring between 100 and $60 \mathrm{ka}$ (mature paleosol), 50 and $30 \mathrm{ka}$ (weak paleosol) and $10 \mathrm{ka}$ (poorly developed paleosol) implying role of climate variability, sediment weathering and provenance and pedogenesis (Srivastava et al., 2015, 2016; 2018). During the early Holocene climatic optimum, high river discharge triggered the river incision (Srivastava et al., 2003a,b; Gibling et al., 2005; Sinha et al., 2005, 2007; Tandon et al., 2006; Shukla et al., 2012; Dingle et al., 2016).

\section{Sedimentation in lower Ganga and Deltaic plains (LGP)}

The River Ganga drains through the alluvial plains from Uttar
Pradesh, Bihar and the hills and uplands of Jharkhand, enters the lower Ganga and deltaic plains (LGP) in West Bengal and finally falls into the Bay of Bengal. The Bengal basin coupled with the offshore Bengal Fan under the Bay of Bengal acts as a large sink for one of the world's largest sediment dispersal systems of Ganges and Brahmaputra Rivers and it forms a large delta system that extends from India to Bangladesh (Goodbred and Kuehl, 2000a; Goodbred, 2003; Mukherjee et al., 2009; Roy and Chatterjee, 2015); it has a combined discharge of $~ 1$-billion-ton sediment load (with insignificant contribution from the Meghna River; Wilson and Goodbred, 2015).

The deposits of the LGP and Bengal plain bear the imprints of monsoon, neotectonic activities and sea-level changes (Allison et al., 2003; Sinha et al., 2005; Tandon et al., 2008; Sinha and Sarkar, 2009; Sarkar et al., 2009; Neidhardt et al., 2013; Auerbach et al., 2015). Based on the chronology and geographic location LGP can be studied under two divisions, viz., (a) the northern part of lower Ganga plains and delta plains (NLGP), north of the Ganga river, and (b) the southern part of lower Ganga plains and delta plains (SLGP) south of the Ganga river (Fig-2).

Northern part of the NLGP is drained by Ganga and its tributaries wherefour major morphostratigraphic units were identified (Pal et al., 1990; Das and Panja, 1999; Panja et al., 2002). This succession was interpreted as ‘Barind Formation' (Unit 4) developed during the regressive phase of the Last Glacial Maxima (LGM) or due to its deposition in the subsiding depression formed as a result of tectonic activities prior to the Holocene (Pal et al., 1990; Panja et al., 2015; Rashid et al., 2015). The oldest flood plain is composed of calichebearing sediments referred toas the Baikunthapur Formation (Unit 3 ). In the exposed section at the Jalpaiguri area (West Bengal), as described by Gupta and Ghatak (2016), it represents a fan apex succession and is dated between $63 \pm 6$ ( $\sim$ MIS-4, weakened monsoon) and $26 \pm 2 \mathrm{ka}$. The overlying Shangaon Formation (Unit-2) was deposited between $9 \pm 0.5$ and 7.4 \pm 0.4 ka,presumably as floodplain deposits (Gupta and Ghatak, 2016). The neotectonic depressions within the Barind plain became the site of deposition forming the Shangaon plain during the Holocene through cut and fill activity of the fluvial regime. The modern-dayfloodplain is divided into two parts, i.e., Tal (west of Mahananda and north portion above the Kalindri River) and Diara (Southernpart below the Kalindri River). The 60 cm thick greyish yellow flood deposit with weakly laminated layers of silt and fine sand from Diara unit (Balupur; located in the acutely meandering loops of the Kalindri) has been OSL dated to $1.2 \pm 0.2 \mathrm{ka}$ (Rajaguru et al., 2011).

Southern part of the lower Ganga and delta plains (SLGP) extends from south and east of the Rajmahal-Garo gap to the modern shoreline. The area is divided into three sub-geomorphic units: Rarh plains, Ganga Delta (upper and lower)and Coastal plain area (Fig. 2). The present Bhagirathi-Hooghly River forms the approximate boundary between the Rarh and Ganga delta.

The Rarh plain is drained by the rivers emerging from the Chhotanagpur plateau and by the distributaries of the Ganga delta (Sengupta, 1966). The river system delivered craton-derived alluvium that formed coalescing paradeltas on the continental shelf (the Bengal basin; Das Gupta and Mukherjee, 2006; Bandyopadhyay et al., 2014; Rudra, 2014) which is identifiable intofour stratigraphic units in order of relative ages (oldest to youngest; Ghosh and Majumder, 1981, 1991; Vaidyanadhan and Ghosh, 1993; Roy and Chattopadhyay, 1997): (a) The LateriticFormation, the oldest unit, rests on the Precambrian boulder conglomerate in the westand on the Gondwana 
and Tertiary (pre-Mio-Pliocene) rocks in the eastern side. The lower part of this formation contains Mio-Pliocene fossil wood,whereas, the upper part is characterized by reworked nodular ferricretes cemented by the ferruginous sandy silt or clay containing mammalian remains of middle to upper Pleistocene age and the Acheulian Palaeolithic tools. The presence of $\sim 75$ ka Toba-AshBed marker has been recorded in the laterite-topped Quaternary profile as well (Acharyya and Basu, 1993; Acharyya et al., 2000) from the Barakar River (a tributary of Damodar) from NW parts of the Raniganj Coalfield which is correlated with the upper part of this formation and assigned the Pleistocene age. (b) A 0.5-12 m thick unit, referred to as the Older Alluvium, comprising ferruginous, brown, compact, sandy loam. This unit contains fragmentary mammalian fossil bones and microlithic artefacts. It is considered to represent terminal Pleistocene to early Holocene age (Basak et al., 1998; Panja et al., 2015). (c) The Younger Alluvium comprising alluvial terrace sediments dated between $5850 \pm 120$ yrs BP and $1290 \pm 100$ yrs BP (Goswami, 1993; Roy and Chattopadhyay, 1997). This unit has also yielded two Thermoluminescence (TL) dates of $1.0 \mathrm{ka}$ and $3.6 \mathrm{ka}$ at $0.35 \mathrm{~m}$ and $0.85 \mathrm{~m}$ depths (Singh et al., 1998). (d) The youngest stratigraphic formation is represented by the present-day floodplain depositsalong the major river channels. It has been dated as late Holocene to the Present usingthe TL dating (900 and 150 yrs BP; Singh et al., 1998).

The late Quaternary period witnessed intense tectonic movements in the LGP due to reactivation of basement faults (Khan, 1991) and tectonic subsidence which controlled the depositional pattern (Stanley and Hait, 2000; Goodbred and Kuehl, 2000a; Goodbred, 2003; Goodbred et al., 2014; Reitz et al., 2015), produced active transgression during early Pleistocene and around 7-6 ka (Banerjee and Sen, 1987; Singh et al., 1998) and shifting (avulsion) of river courses (Rudra, 1999; Chakrabarti et al., 2001; Bandyopadhyay, 2007; Gupta et al., 2014; Rudra, 2014; Rogers and Goodbred, 2014; Das, 2015).

\section{Ganga delta}

The Upper Ganga delta represents an interfluvial delta plain, which extends from eastern limit of the Rarh plains, i.e., meander belt of the Bhagirathi-Hooghly to the Lower Ganga delta (Fig 2). Besides the meander belt, the western edge of the Upper Ganga delta is also defined by its paleo-distributaries like the Saraswati and the lower Rupnarayan (Bandyopadhyay et al., 2014, 2015). The earlier studies on subsurface stratigraphy of the Upper Ganga delta reported five major stratigraphic units (McArthur et al., 2008; Sarkar et al., 2009). The lowermost ( $30 \mathrm{~m}$ thick) Pleistocene shelf is constituted entirely of grey to dark grey clay. The overlying lenticular sediment bodies formed as channel fills in alluvial valleys during low sealevelstands are dated as $\sim 32 \mathrm{ka}$ (Hait et al.,1996). The next unit represents the LGM low stand and related paleosols that are made up of bioturbated brown clay calcretized towards the top. The sediment cores raised from this unit from Kolkata and Diamond Harbour by Hait et al.(1996) and Stanley and Hait (2000) yielded ages of 24 ka and $14 \mathrm{ka}$, respectively. Besides, an incised fluvial valley fill deposit was also recorded during the LGM from the same unit (Sarkar et al., 2009). The early Holocene estuarine valley-fill/aggrading fluvial channel sand, overbanks and peat swamps are well preserved as the next unit. The lower part of this unit represents an estuarine valley fill and the upper part corresponds to aggrading fluvial channeloverbank system. It has been suggested that the aggradation of fluvial channel-overbank system was rapid, often depositing $>10 \mathrm{~m}$ sand in less than a kilo-year as inferred from the OSL dates (e.g., 7.6-7.1 ka) (Sarkar et al., 2009). The topmost capping unit consistsof silt in the lower part with decreased concentration of mangrove pollen and fine sand in the upper part with thin interfingering silts.

The Lower Ganga delta comprises part of Sundarbans between the Hooghly and the Hariabhanga rivers on the India-Bangladesh border with an area of $\sim 9441 \mathrm{~km}^{2}$ and the inland limit is taken as 70 $100 \mathrm{~km}$ from the present shoreline close to the maximum transgression point (Sinha and Sarkar, 2009; Bandyopadhyay et al., 2014). This portion is the abandoned part of the delta in the west, comprising non-fluvial regime.Thefluvial regimeabandoned prior to $\sim 5 \mathrm{ka}$, as the Ganges River migrated eastward towards its present position 
(Goodbred and Kuehl, 2000a; Sarkar et al., 2009; Rogers et al., 2013; Flood et al., 2018). The Lower Ganga delta is now thought to be undergoing net delta front erosion, possibly reflecting erosive mode of marine and tidal processes (Bandyopadhyay and Bandyopadhyay, 1996; Allison, 1998; Allison et al., 2003; Flood et al., 2016). A series of channels were abandoned as the Ganges shifted from west (i.e., Bhagirathi-Hooghly River) to its current position in the east. For the last $\sim 4 \mathrm{ka}$, the area is dominated by the estuarine tidal processes. The Lower Ganga delta also marks the limit of saline water penetration from the Bay of Bengal along these distributary channels during the dry season (Goodbred and Kuehl, 2000b). So far as the Quaternary stratigraphy is concerned, based on sediment texture, five major lithostratigraphic units have been identified in boreholes across the Lower Ganga delta: Muddy Sand (MS), Mottled Mud (MM), Interbedded Mud (IM), Laminated Sand (LS), and Peaty Mud (PM) (Allison et al., 2003; Flood et al., 2018). The Lower delta mud facies consist of both marine and terrestrial fossils, which represent a marineinfluenced mangrove environment during early Holocene sea-level rise (Heroy et al., 2003). A muddy sand facies is overlying this and interpreted as prograding fluvial and estuarine distributary mouth deposits and formed during 8-3.5 ka. Over most of this area, several meters of floodplain deposits formed during the last 5 ka part of the thin Mud facies, cap the sequence.

Based on sub-surface lithology and ${ }^{14} \mathrm{C}$-AMS dating, it is suggested that during the early to mid-Holocene rise in sea level, the delta was receiving sediments at the rates that are double than the present and during this time, the Ganga delta actively prograded (Goodbred, 2003; Goodbred et al., 2014).Besides the erosion in Himalaya and Ganga Plains, large lake outburst floods are envisaged as cause of large sediment supply and channel changes (Pickering et al., 2018). The rapid sedimentation, channel avulsions and sea-level changes in deltaic zones created a non-uniform subsidence that has recently been recognized and that suggests a seaward increasing subsidence rates varying from $<0.2$ to $\sim 5 \mathrm{~mm} / \mathrm{yr}$ (Grall et al., 2018).

\section{Discussion}

The Himalayan mountain, its foreland and deltaic zone constitute a coupled system. The rivers originating in the Himalayan and cratonic regions usually show three zones, viz., source zone (i.e., the Himalayan mountains and craton), transportation and transient storage zone (i.e., the Indo-Gangetic-Bramhaputra plains), and deposition zone (i.e., lower Ganga and deltaic plains). Large variability is observed in terms of climate and tectonics in the source region-precipitation as well as the rate of tectonic convergence, both varies from the eastern and central Himalaya to the western Himalaya (Banerjee and Bürgmann, 2002). Variation in the rates of convergence and precipitation should produce different responses; however, in general, we observe similar responses in terms of sediment generation and deposition in most valleys of the Himalaya. The Himalayan Rivers largely aggraded in response to enhanced SW monsoon of MIS-1 and MIS-3 while they incisedduring the monsoon maxima in the late Pleistocene and Holocene. The rates of incision, at places, is controlled by the tectonic activity along the major faults of the Himalaya, especially in the frontal Himalayan part. The hillslope processes, and trunk-river and tributary interaction driven by the enhanced monsoon, largely governed the valley aggradation. An extreme hydrological event of June 2013 in Kedarnath suggests that (i) the hotspots of erosion and valley aggradation in response to extreme hydrological events are predictable, and (ii) such events must have occurred in the past, but understanding of their future frequency and magnitude requires systematic geomorphic and chronological studies across the Himalaya. The Himalayan frontal landscape is characterized by the Duns (intermontane valleys) and large alluvial fans. These landscapes show strong link of aggradation with the strengthening of the monsoon; however, presence of accommodation space is significantly controlled by the movement along the HFT. Also, tectonics have deformed the landforms in some frontal parts of the Himalaya indicating its influence on the sedimentation in this region.

The studies in the Ganga Plain exhibit sedimentation at variable rates occurring in the past $\sim 120 \mathrm{ka}$. However, there is a contrast in the geomorphology of the eastern and the western Ganga plains. The rivers in the western plains are incised whereas, those in the eastern plains are hyper-avulsive-largely due to the varying convergence rates, sediment flux, and stream power. Based on the recent studies, the sedimentation in the Ganga plain can be summarized as follows: the Ganga plain actively aggraded between $>100 \mathrm{ka}$ and $<10 \mathrm{ka}$, with phases of non-deposition/incision during the LGM and also during wetter spells (which is supported by the regionally correlatable paleosol surfaces). The Ganga Plains predominantly received the sediments from the Himalaya, except in the southern Ganga Plains where the sediments were supplied from the Bundelkhand plateau, and the peripheral bulge region of the Ganga Plain (Sinha et al., 2009; Ghosh et al., 2019). In the southern Ganga Plain, ravine is one of the important geomorphic features in the interfluve region and studies suggest that tectonics and incision of river valley control the ravine growth. The specific sediment yield of these ravines varies between $600 \pm 100 \mathrm{t} / \mathrm{km}^{2} / \mathrm{yr}$ and $1600 \pm 200 \mathrm{t} / \mathrm{km}^{2} / \mathrm{yr}$ (Joshi, 2014; Ghosh et al., 2018), which is far higher than $\sim 238 \mathrm{t} / \mathrm{km}^{2} / \mathrm{yr}$ as estimated for the Central Ganga Plain (Wasson et al., 2013) and way less than the erosion rates in the Himalaya (e.g., erosion rate of a terrace in the Lesser Himalaya was estimated to be $~ 3350 \mathrm{t} / \mathrm{km}^{2} / \mathrm{yr}$ ).

In the distal part, the sedimentation is strongly controlled by the sea level and precipitation changes. Lowering of sea level during the LGM resulted in the development of deep incised valleys which were later filled during the onset of the interglacial period. Doubling of sedimentation occurred during the period of increased precipitation. A direct correlation with the precipitation gives rise to an important issue about the connectivity between the source and the sink. The question arises that what is the lag period between sediments originating in the source zone and reaching the depositional zone? How this lag period varies with the changing precipitation rates? What fraction of the sediment originating in the source zone reaches the sink? These are some of the important questions for the future research in this terrain.

\section{Conclusions}

The Himalayan system comprising the hinterland, foreland, forebulge and deltas is one of the most dynamic systems on the earth. Studies in the past decade have focused on determining controls of tectonics and climate on sedimentation in the Himalayan mountains and the Indo-Gangetic plains. A strong control of climate is observed in the sedimentation within the Himalayan river valleys, the IGP and the deltas. In general, the rivers demonstrate large scale aggradation during the LGM and incision during the strengthening of the monsoon between 12-9 ka. Valley-scale aggradation is observed in the Himalaya during the glacial to interglacial transition period; aggradation in the 
IGP is also observed prior to the LGM. Incision in the deltaic region occurred during the LGM and doubling of sedimentation occurred during intensification of monsoon, demonstrating strong connectivity between the source and the sink during this period. Despite the considerable research work, there still remain certain gap areas that need to be addressed.

\section{References}

Abrahami, R., Huyghe, P., van der Beek, P., Lowick, S., Carcaillet, J. and Chakraborty, T., 2018, Late Pleistocene-Holocene development of the Tista megafan (West Bengal, India): 10 Be cosmogenic and IRSL age constraints. Quaternary Science Reviews, v. 185, pp. 69-90.

Acharyya, S.K. and Basu, P.K., 1993, Toba Ash on the Indian Subcontinent and its implications for correlation of Late Pleistocene Alluvium. Quaternary Research, v. 40, pp.10-19.

Acharyya, S.K., Lahiri, S., Raymahashay, B.C. and Bhowmik, A., 2000, Arsenic toxicity of groundwater in parts of the Bengal basin in India and Bangladesh: the role of Quaternary stratigraphy and Holocene sea-level fluctuation. Environmental Geology, v. 39 (10), pp. 1127-1137.

Agarwal, K.K., Singh, I.B., Sharma, M., Sharma, S.Rajagopalan and G., 2002, Extensional tectonic activity in the cratonward parts (peripheral bulge) of the Ganga Plain foreland basin, India. International Journal of Earth Sciences, v. 91, pp.897-905.

Agrawal, S., Sanyal, P., Balakrishnan, S. and Dash, J.K., 2013, Exploring the temporal change in provenance encoded in the late Quaternary deposits of the Ganga Plain. Sedimentary Geology, v. 293, pp. 1-8.

Allison, M.A., 1998, Historical changes in the Ganges-Brahmaputra delta. Journal of Coastal Research, v. 14, pp. 1269-1275.

Allison, M.A., Khan, S.R., Goodbred Jr., S.L. and Kuehl, S.A., 2003, Stratigraphic evolution of the late Holocene Ganges-Brahmaputra lower delta plain. Sedimentary Geology, v. 155, pp. 317-342.

Anoop, A., Prasad, S., Basavaiah, N., Brauer, A., Shahzad, F. and Deenadayalan, K., 2012, Tectonic versus climate influence on landscape evolution: a case study from the upper Spiti valley, NW Himalaya. Geomorphology, v. 145, pp.32-44.

Auerbach, L.W., Goodbred Jr., S.L., Mondal, D.R., Wilson, C.A., Ahmed, K.R., Roy, K., Steckler, M.S., Small, C., Gilligan, J.M. and Ackerly, B.A., 2015, Flood risk of natural and embanked landscapes on the Ganges-Brahmaputra tidal delta plain. Nature Climate Change, v. 5, pp. 153-157.

Bandyopadhyay, S, 2007, Evolution of the Ganga-Brahmaputra delta: a review: Geographical Review of India, v. 69, 3, pp. 235-268.

Bandyopadhyay, S., and Bandyopadhyay, M.K., 1996, Retrogradation of the western Ganga-Brahmaputra delta, India and Bangladesh: Possible reasons. In: Tiwari, R.C. (Ed.), Proceedings of $6^{\text {th }}$ Conference of Indian Institute of Geomorphologists. National Geographer, v. 31, pp. 105-128.

Bandyopadhyay, S., Das, S. and Kar, N.S., 2015, Discussion: Changing river courses in the western part of the GangaBrahmaputra delta by Kalyan Rudra (2014), Geomorphology, 227, 87-100, Geomorphology, v. 250, pp. 442-453,

Bandyopadhyay, S., Kar, N.S., Das, S. and Sen, J., 2014, River Systems and Water Resources of West Bengal: A Review. In: Vaidyanadhan, R. (ed.), Rejuvenation of Surface Water Resources of India: Potential, Problems and Prospects. Geological Society of India, Special Publication 3, pp. 63-84.

Banerjee, M., and Sen, P.K., 1987, Paleobiology in understanding the change of sea-level and coast line in Bengal Basin during the Holocene period. Indian Journal of Earth Sciences, v. 14, pp.
307-320.

Banerjee P, Bürgmann R, 2002, Convergence across the northwest Himalaya from GPS measurements. Geophysical Research Letters, v. 29,13 , pp. $30-1$

Basak, B., Badam, G.L., Kshirsagar, A. and Rajaguru, S.N., 1998, Late Quaternary Environment, Palaeontology and Culture of Tarafeni Valley, Midnapore District, West Bengal: A Preliminary Study. Journal Geological Society of India, Vol. 51 (6), pp. 731740.

Bawa, N., Jain, V., Shekhar, S., Kumar, N. and Jyani, V., 2014, Controls on morphological variability and role of stream power distribution pattern, Yamuna River, western India. Geomorphology, 227, pp. 60-72.

Blöthe, J.H., Munack, H., Korup, O., Fülling, A., Garzanti, E., Resentini, A. and Kubik, P.W., 2014, Late Quaternary valley infill and dissection in the Indus River, western Tibetan Plateau margin. Quaternary Science Reviews, v. 94, pp.102-119.

Blum, M.D. and Törnqvist, T.E., 2000, Fluvial responses to climate and sea level change: a review and look forward. Sedimentology, v. 47, pp.2-48.

Bookhagen, B., and Burbank, D.W., 2010, Toward a complete Himalayan hydrological budget: Spatiotemporal distribution of snowmelt and rainfall and their impact on river discharge. Journal of Geophysical Research, v. 115, pp.1-25.

Bookhagen, B., Fleitmann, D., Nishiizumi, K., Strecker, M.R., and Thiede, R.C., 2006, Holocene monsoonal dynamics and fluvial terrace formation in the northwest Himalaya, India. Geology, v. 34, pp. 601-604, DOI:10.1130/G22698.1.

Bookhagen, B., Thiede, R.C., and Strecker M.R., 2005, Late Quaternary intensified monsoon phases control landscape evolution in the northwest Himalaya. Geology, v. 33, pp.149152.

Burbank, D.W., Leland, J., Fielding, E., Anderson, R., Brozovic, N., Reid, M., and Duncan, C., 1996 b, Bedrock incision, rock uplift and threshold hillslopes in the northwestern Himalayas. Nature, v. 379, pp.505-510. DOI: 10.1038 /379505a0.

Burbank, D.W., Richard, A.B. and Mulder, T. 1996 a, The Himalayan foreland basin. In: Yin, A., \& Harrison, M.T. (eds.), The tectonic evolution of Asia, Cambridge University Press, USA, pp. 149188.

Chahal, P., Kumar, A., Sharma, C.P., Singhal, S., Sundriyal, Y.P. and Srivastava, P., 2019, Late Pleistocene history of aggradation and incision, provenance and channel connectivity of the Zanskar River, NW Himalaya. Global and Planetary Change,v. 178, pp.110-128.

Chakrabarti, P, Nag, S. and Mitra, A.K., 2001, Changing drainage pattern of the Ganga-Bhagirathi system in historic times: a study based on Remote Sensing Technology. Indian Journal of Geology, v. 73(1), pp. 35-41.

Chakraborty, T., Forman, S., Ghosh, P., Kar, R. and Basu, S., 2010, New luminescence dates from Tista megafan, eastern Himalaya and its implications for evolution of the foreland basin-fill. Geophysical Research Abstracts. pp. 13707.

Chakraborty, T. and Ghosh, P., 2010, The geomorphology and sedimentology of the Tista megafan, Darjeeling Himalaya: Implications for megafan building processes. Geomorphology, v. 115, 252-266. DOI:10.1016/j.geomorph.2009.06.035

Chaudhary, S., Shukla, U.K., Sundriyal, Y.P., Srivastava, P. and Jalal, P., 2015, Formation of paleovalleys in the Central Himalaya during valley aggradation. Quaternary International, v. 371, pp. 254267. DOI:10.1016/j.quaint.2014.12.064

Das Gupta, A.B. and Mukherjee, B., 2006, Geology of NW Bengal Basin. Geological Society of India, Bangalore, pp. 57.

Das, A. and Sheena Panja, 1999, Cultural History of Malda and South 
Dinajpur, West Bengal: A Geoarchaeological Perspective. Gondwana Geological Magazine, v. 4, pp. 347-349.

Das, G.K., 2015, Estuarine Morphodynamics of the Sunderbans. Springer, Berlin, 10 p.

Das, S., Kar, N.S. and Bandyopadhyay, S., 2015, Glacial lake outburst flood at Kedarnath, Indian Himalaya: a study using digital elevation models and satellite images. Natural Hazards, v. 77, pp. 769-786. DOI:10.1007/s11069-015-1629-6

De Sigoyer, J., Guillot, S. and Dick, P., 2004, Exhumation of the ultrahigh pressure Tso Morari unit in eastern Ladakh (NW Himalaya). A case study. Tectonics, v. 23, pp. 1-18.

Devrani, R., Singh, V., Mudd, S.M. and Sinclair, H.D., 2015, Prediction of flash flood hazard impact from Himalayan river profiles. Geophysical Research Letters, v. 42(14), pp.5888-5894.

Devrani, R. and Singh, V., 2014, Evolution of valley-fill terraces in the Alaknanda Valley, NW Himalaya: its implication on river response studies. Geomorphology, v. 227, pp. 112-122.

Dey, S., Thiede, R.C., Schildgen, T.F., Wittmann, H., Bookhagen, B., Scherler, D., Jain, V. and Strecker, M.R., 2016, Climate-driven sediment aggradation and incision since the late Pleistocene in the NW Himalaya, India. Earth Planetary Science Letters, v. 449, pp. 321-331. DOI:10.1016/j.epsl.2016.05.050

Dingle, E.H., Sinclair, H.D., Attal, M., Milodowski, D.T. and Singh, V., 2016, Subsidence control on river morphology and grain size in the Ganga Plain. American Journal of Science, v. 316, pp. 778812.

Dortch, J.M., Owen, L.A., Haneberg, W.C., Caffee, M.W., Dietsch, C. and Kamp, U., 2009, Nature and timing of large landslides in the Himalaya and Trans Himalaya of northern India. Quaternary Science Reviews, v. 28, pp.1037-1054.

Dortch, J.M., Owen, L.A. and M.W., 2010, Quaternary glaciation in the Nubra and Shyok valley confluence, northernmost Ladakh, India. Quaternary Research, v. 74, pp. 132-144, DOI:10.1016/ j.yqres.2010.04.013.

Dosseto, A. and Vigier, N., 2015, Rapid response of silicate weathering rates to climate change in the Himalaya. Geochemical Perspective Letters, v. 1, pp. 10-19. DOI:10.7185/geochemlet.1502

Dutta, S., Mujtaba, S.A.I., Saini, H.S., Chunchekar, R. and Kumar, P., 2018, Geomorphic evolution of glacier-fed Baspa Valley, NW Himalaya: record of Late Quaternary climate change, monsoon dynamics and glacial fluctuations. Geological Society, London, Special Publications, v. 462(1), pp.51-72.

Dutta, S., Suresh, N. and Kumar, R., 2012, Climatically controlled Late Quaternary terrace staircase development in the fold- and thrust belt of the Sub Himalaya. Paleogeography, Paleoclimatelogy, Paleoecology, v. 356-357, pp. 16-26. DOI:10.1016/j.palaeo.2011.05.006

Flood, R.P., Barr, I.D., Weltje, G.J., Roberson, S., Russell, M.I., Meneely, J. and Orford, J.D., 2018, Provenance and depositional variability of the Thin Mud Facies in the lower GangesBrahmaputra delta, West Bengal Sundarbans, India. Marine Geology, v. 395, pp. 198-218.

Flood, R.P., Bloemsma, M.R., Weltje, G.J., Barr, I.D., O’Rourke, S.M., Turner, J.N. and Orford, J.D., 2016, Compositional data analysis of Holocene sediments from the West Bengal Sundarbans, India: Geochemical proxies for grain-size variability in a delta environment. Applied Geochemistry, v. 75, pp. 222-235.

Ghosh, R., Sehgal, R.K., Srivastava, P., Shukla, U.K., Nanda, A.C. and Singh, D.S., 2016, Discovery of Elephas cf. namadicus from the late Pleistocene strata of Marginal Ganga Plain. Journal of Geological Society of India, v. 88, pp. 559-568. https://doi.org/ 10.1007/s12594-016-0521-7

Ghosh, R., Srivastava, P., Shukla, U.K., Singh, I., Ray, P.C. and Sehgal, R.K., 2018, Tectonic forcing of evolution and Holocene erosion rate of ravines in the Marginal Ganga Plain, India. Journal of Asian Earth Sciences, v. 162, pp. 137-147.

Ghosh, R., Srivastava, P., Shukla, U.K., Sehgal, R.K. and Singh, I.B., 2019, 100 kyr sedimentary record of Marginal Gangetic Plain: Implications for forebulge tectonics. Palaeogeography, Palaeoclimatology, Palaeoecology, v. 520, pp. 78-95.

Ghosh, R.N. and Majumdar, S., 1981, Neogene-Quaternary Sequence of Kasai Basin, West Bengal, India. Proceedings of Neogene/ Quaternary Boundary Field Conference, India, 1979, pp. 63-73.

Ghosh, R.N. and Majumder, S., 1991, Geology and morphostratigraphy of West Bengal: a database for archaeological exploration. In A. Dutta (Ed.), Studies in Archaeology (pp. 740). New Delhi: Books and Books.

Gibling, M.R., Tandon, S. K., Sinha, R. and Jain, M., 2005, Discontinuity-bounded alluvial sequences of the southern Gangetic plains, India: aggradation and degradation in response to monsoonal strength. Journal of Sedimentary Research, v. 75, pp. 369-385.

Goodbred Jr., S.L., 2003, Response of the Ganges dispersal system to climate change: a source-to-sink view since the last interstade. Sedimentary Geology, v. 162, pp. 83-104.

Goodbred, S.L. and Kuehl, S.A., 2000a, Enormous GangesBrahmaputra sediment discharge during strengthened early Holocene monsoon. Geology, v. 28 (12), pp. 1083-1086.

Goodbred, S.L. and Kuehl, S.A., 2000b, Enormous GangesBrahmaputra sediment discharge during strengthened early Holocene monsoon. Geology, v. 28(12), pp. 1083-1086. https:// doi.org/10.1130/0091-7613(2000)28<1083:EGSDDS>2.0.CO;2

Goodbred, S.L., Paolo, P.M., Ullah, M.S., Russell D. Pate, R.D., Khan, S.R., Kuehl, S.A., Singh, S.K. and Rahaman, W., 2014, Piecing together the Ganges-Brahmaputra-Meghna River delta: Use of sediment provenance to reconstruct the history and interaction of multiple fluvial systems during Holocene delta evolution. Geological Society of America Bulletin, v. 126 (11-12), pp. 14951510.

Goswami, A.B., 1993, Review on Quaternary geological mapping and standardization of scheme of classification for interbasin regional correlation of Quaternary units in east and northeast India. GSI Rec., v. 121, pp. 55-85.

Goswami, P.K. and Mishra, J.K., 2013, Climatic and tectonic controls on the sedimentary processes of an alluvial fan of the western Ganga Plain, India. Geological Magazine, v. 150, pp. 240-253, DOI:10.1017/S0016756812000490.

Grall, C., Steckler, M.S., Pickering, J.L., Goodbred, S., Sincavage, R., Paola, C., Akhter, S.H. and Spiess, V., 2018, A base-level stratigraphic approach to determining Holocene subsidence of the Ganges-Meghna-Brahmaputra Delta plain. Earth and Planetary Science Letters, 499, pp. 23-36.

Gupta, N., Kleinhans, M.G., Addink, E.A., Atkinson, P.M. and Carling, P.A., 2014, One-dimensional modelling of a recent Ganga avulsion: assessing the potential effect of tectonic subsidence on a large river. Geomorphology, v. 213, pp. 24-37.

Gupta, S. and Ghatak, S., 2016, Decoding fluvial archives along River Tista at the frontal Himalayan foreland, India. Abstracts, 35th International Geological Congress 2016, Cape Town, South Africa, August 27 - September 04 2016, T42 (12), Paper Number: 413.

Hait, A.K., Das, H.K., Ghosh S., Ray, A.K. and Chanda, S., 1996, Environmental variations in the late Quaternary sequence of Kolaghat, West Bengal, India. Current Science, v. 70 (12), pp. 1089-1093.

Heroy, D.C., Kuehl, S.A. and Goodbred, S.L., Jr., 2003, Mineralogy of the Ganges and Brahmaputra Rivers: Implications for river switching and Late Quaternary climate change. Sedimentary 
Geology, v. 155 (3-4), pp. 343-359.

Hodges, K.V., Wobus, C.W., Ruhl, K., Schildgen, T. and Whipple, K.X., 2004, Quaternary deformation, river steepening, and heavy precipitation at the front of the Higher Himalayan ranges. Earth and Planetary Science Letters, v. 220, pp. 379-389, DOI:10.1016/ S0012-821X(04)00063-9.

Jain, A.K. and Singh, S., 2008, Tectonics of the southern Asian Plate margin along the Karakoram Shear Zone: Constraints from field observations and U-Pb SHRIMP ages. Tectonophysics, v. 451(14), pp.186-205.

Jain, M. and Tandon, S.K., 2003, Fluvial response to Late Quaternary climate changes, western India. Quaternary Science Journal, v. 22, pp. 2223-2235, DOI:10.1016/S0277-3791(03)00137-9.

Jain, V. and Sinha, R., 2004, Fluvial dynamics of an anabranching river system in Himalayan foreland basin, Baghmati River, north Bihar plains, India. Geomorphology, v. 60, pp. 147-170.

Jonell, T.N., Owen, L.A., Carter, A., Schwenniger, J.L. and Clift, P.D., 2018, Quantifying episodic erosion and transient storage on the western margin of the Tibetan Plateau, upper Indus River. Quaternary Research, v. 89(1), pp.281-306.

Joshi, V.U., 2014, The Chambal Badlands. In Landscapes and Landforms of India (pp. 143-149). Springer, Dordrecht.

Juyal, N., Sundriyal, Y.P., Rana, N., Chaudhary, S. and Singhvi, A.K., 2010, Late Quaternary fluvial aggradation and incision in the monsoon-dominated Alaknanda valley, Central Himalaya, Uttrakhand, India. Journal of Quaternary Science, v. 25, pp.12931304.

Khan, A.A., 1991, Tectonics of the Bengal Basin. Journal of Himalayan Geology, v. 2, 1, pp. 91-101.

Korup, O., Clague, J.J., Hermanns, R.L., Hewitt, K., Strom, A.L. and Weidinger, J.T., 2007, Giant landslides, topography, and erosion. Earth and Planetary Science Letters, v. 261 (3), pp.578-589.

Kumar, A. and Srivastava, P., 2017. The role of climate and tectonics in aggradation and incision of the Indus River in the Ladakh Himalaya during the late Quaternary. Quaternary Research, v. 87(3), pp.363-385.

Kumar, R. and Sangode, S.J., 2007, Differential features of alluvial fans in the Pinjaur-Soan Dun, NW Himalaya, India/ : controlling factors. Himalayan Geology, v. 28, pp. 37-46.

Kumar, R., Suresh, N., Sangode, S.J. and Kumaravel, V., 2007, Evolution of the Quaternary alluvial fan system in the Himalayan foreland basin: implications for tectonic and climatic decoupling. Quaternary International, v. 159, pp. 6-20.

Kumar, S., Wesnousky, S.G., Rockwell, T.K., Ragona, D., Thakur, V.C. and Seitz, G.G., 2001. Earthquake Recurrence and Rupture Dynamics of Himalayan Frontal Thrust, India. Science, v. (80) 294, pp. 2328-2331.

Lal, R., Saini, H.S., Pant, N.C. and Mujtaba, S.A.I., 2019, Tectonics induced switching of provenance during the Late Quaternary aggradation of the Indus River Valley, Ladakh, India. Geoscience Frontiers, DOI:10.1016/j.gsf.2017.12.016.

Lave, J. and Avouac, J.P., 2000, Active folding of fluvial terraces across the Siwaliks Hills, Himalayas of central Nepal. Journal of Geophysical Research, v. 105, pp. 5735-5770.

Leland, J., Reid, M.R., Burbank, D.W., Finkel, R. and Cafee, M., 1998, Incision and differential bedrock uplift along the Indus River near Nanga Parbat, Pakistan Himalaya, from 10Be and 26Al exposure age dating of bedrock straths. Earth and Planetary Science Letters, v. 154, pp.93-107.

McArthur, J.M., Ravenscroft, P., Banerjee, D.M., Milsom, J., HudsonEdwards, K.A., Sengupta, S., Bristow, C., Sarkar, A., Tonkin, S. and Purohit, R., 2008, How paleosols influence groundwater flow and arsenic pollution: A model from the Bengal Basin and its worldwide implication. Water Resources Research, v. 44 (11),
W11411.

Meetei, L.I., Pattanayak, S.K. and Bhaskar, A., 2007, Climatic imprints in Quaternary valley-fill deposits of the middle Teesta valley, Sikkim Himalaya. Quaternary International, v. 159, pp. 32-46.

Molnar, P., 1984, Structure and tectonics of the Himalaya: constraints and implications of geophysical data. Annual Review of Earth Planetary Science, v. 12, pp. 489-518.

Mukherjee, A., Fryar, A.E. and Thomas, W.A., 2009, Geologic, geomorphic and hydrologic framework and evolution of the Bengal basin, India and Bangladesh. Journal of Asian Earth Sciences, v. 34, pp. 227-244.

Nag, D. and Phartiyal, B., 2015. Climatic variations and geomorphology of the Indus River valley, between Nimo and Batalik, Ladakh (NW Trans Himalayas) during Late Quaternary. Quaternary International, v. 371, pp. 87-101. DOI 10.1016/ j.quaint.2014.08.045

Nag, D., Phartiyal, B. and Singh, D.S., 2016, Sedimentary characteristics of palaeolake deposits along the Indus River valley, Ladakh, Trans Himalaya: Implications for the depositional environment. Sedimentology, v. 63(6), pp. 1765-1785.

Neidhardt, H., Biswas, A., Freikowski, D., Majumder, S., Chatterjee, D. and Berner, Z.A., 2013, Reconstructing the sedimentation history of the Bengal Delta Plain by means of geochemical and stable isotopic data. Applied Geochemistry, v. 36, pp. 70-82.

Owen, L.A., Finkel, R.C., Haizhou, M. and Barnard, P.L., 2006, Late Quaternary landscape evolution in the Kunlun Mountains and Qaidam Basin, Northern Tibet: a framework for examining the links between glaciation, lake level changes and alluvial fan formation. Quaternary International, v. 154, pp.73-86.

Pal, D.K., Bhattacharyya, T., Sinha, R., Srivastava, P., Dasgupta, A.S., Chandran, P., Ray, S.K. and Nimje, A., 2012, Clay minerals record from Late Quaternary drill cores of the Ganga Plains and their implications for provenance and climate change in the Himalayan Foreland. Palaeogeography, Palaeoclimatology, Palaeoecology, v. 356, pp. 27-37.

Pal, S.K., Ghosh, S.S., Das, A., Islam, Md. A. and Biswas, J.K., 1990, Quaternary Geological and Geomorphological Mapping in Mahananda Basin in parts of West Dinajpur and Malda Districts, West Bengal. Records of the Geological Survey of India, v. 123 (3), pp. 25-26.

Pandey, A.K., Pandey, P., Singh, G.D. and Juyal, N., 2014, Climate footprints in the Late Quaternary - Holocene landforms of Dun Valley, NW Himalaya, India. Current Science, v. 106, pp. 245253.

Panja, S, Nag, A.K. and Bandyopadhyay, S., 2015, Living with floods: Archaeology of a settlement in the lower Ganga plains, c. 6001800 CE. Primus Books, Delhi.

Panja, S., Basak, B., Chakraborty, S., Roychowdhury, S. and Rajaguru, S.N., 2002, Preliminary Geoarchaeological Studies in West Bengal: Man and Environment, v. 27, 2, pp. 45-60.

Pant, R.K., Phadtare, N.R., Chamyal, L.S. and Juyal, N., 2005, Quaternary deposits in Ladakh and Karakoram Himalaya/ : A treasure trove of the palaeoclimate records. Current Science, v. 88, pp. 1789-1798.

Parkash, B., Sharma, R.P. and Roy, A.K., 1980, The Siwalik Group (Molasse)- Sediments shed by Collision of Continental Plates. Sedimentary Geology, v. 25, pp. 127-159.

Paul, S.K., Mehrotra, R.C., Sharma, A., Phartiyal, B. and Dorjey, C.P., 2007. A new fossil palm leaf from the Hemis Formation of Ladakh, Jammu and Kashmir, India. Current Science, v. 92(6), pp.727-729.

Phartiyal, B., Sharma, A., Srivastava, P. and Ray, Y., 2009 a, Chronology of relict lake deposits in the Spiti River, NW Trans Himalaya: Implications to Late Pleistocene-Holocene climate- 
tectonic perturbations. Geomorphology, v. 108(3-4), pp.264-272.

Phartiyal, B., Sharma, A., Upadhyay, R. and Sinha, A.K., 2005, Quaternary geology, tectonics and distribution of palaeo- and present fluvio/glacio lacustrine deposits in Ladakh, NW Indian Himalaya — a study based on field observations. Geomorphology, v. 65, pp. 241-256, DOI:10.1016/j.geomorph.2004.09.004.

Phartiyal, B., Singh, R. and Kothyari, G.C., 2015, Late-Quaternary geomorphic scenario due to changing depositional regimes in the Tangtse Valley, Trans-Himalaya, NW India. Palaeogeography, palaeoclimatology, palaeoecology, v. 422, pp.11-24.

Phartiyal, B., Srivastava, P. and Sharma, A., 2009b, Tectono-Climatic signatures during late Quaternary Period from Upper Spiti Valley, NW Himalaya, India. Himalayan Geology, v. 30(2), pp.10-17.

Pickering, J.L., Goodbred Jr, S.L., Beam, J.C., Ayers, J.C., Covey, A.K., Rajapara, H.M., and Singhvi, A.K., 2018, Terrace formation in the upper Bengal basin since the Middle Pleistocene:Brahmaputra fan delta construction during multiple highstands. Basin Research, v. 30 (Suppl. 1), pp. 550-567.

Rahaman, W., Singh, S.K., Sinha, R. and Tandon, S.K., 2009, Climate control on erosion distribution over the Himalaya during the past 100 ka. Geology, v. 37, pp. 559-562. https://doi.org/10.1130/ G25425A.1

Rajaguru, S.N., Deotare, B.C., Gangopadhyay, K., Sain, M.K. and Panja, S. 2011, Potential geoarchaeological sites for luminescence dating in the Ganga Bhagirathi-Hugli Delta, West Bengal, India. Geochronometria, v. 38 (3), pp. 282-291.

Rashid, B., Ul-Islam, S. and Islam, B., 2015, Sub-Surface Geology and Evolution of the Barind Tract, Bangladesh. American Journal of Earth Sciences, v. 2(2), pp. 22-38.

Ray, Y. and Srivastava, P., 2010, Widespread aggradation in the mountainous catchment of the Alaknanda Ganga River System: timescales and implications to Hinterland foreland relationships. Quaternary Science Reviews, v. 29, pp. 2238-2260, DOI: 10.1016/ j.quascirev.2010.05.023.

Ray, Y., Srivastava, P. and Sundriyal, Y.P., 2011, Evaluating a Paraglacial Hypothesis in Alaknanda River Valley, NW Himalaya, in: Singh, D. Sen, Chhabra, N.L. (Eds.), Geological Processes and Climate Change. Macmillan Publishers India Ltd., pp. 281292.

Reitz, M.D., Pickering, J.L., Goodbred, S.L., Paola, C., Steckler, M.S., Seeber, L. and Akhter, S.H., 2015, Effects of tectonic deformation and sea level on river path selection: Theory and application to the Ganges-Brahmaputra-Meghna River Delta. Journal Geophysical Research Earth Surface, v. 120, pp. 671-689.

Rogers, K.G. and Goodbred Jr., S.L 2014, The Sundarbans and Bengal Delta: The World's Largest Tidal Mangrove and Delta System. In Kale, V.S. (ed.), Landscapes and Landforms of India, World Geomorphological Landscapes, Springer, pp. 181-187.

Rogers, K.G., Goodbred, S.L., Jr. and Mondal, D.R., 2013, Monsoon sedimentation on the 'abandoned' tide-influenced GangesBrahmaputra delta plain. Estuarine, Coastal and Shelf Science, v. 131, pp. 297-309.

Roy, A.B. and Chatterjee, A., 2015, Tectonic framework and evolutionary history of the Bengal Basin in the Indian subcontinent. Current Science, v. 109 (2), pp. 271-279.

Roy, N.G., Sinha, R. and Gibling, M.R., 2012, Aggradation, incision and interfluve flooding in the Ganga Valley over the past 100,000 years: testing the influence of monsoonal precipitation. Palaeogeography, Palaeoclimatology, Palaeoecology, v. 356-357, pp. 38-53.

Roy, R.K. and Chattopadhyay, G.S., 1997, Quaternary Geology of the Environs of Ganga Delta, West Bengal and Bihar. Indian Journal of Geology, v. 69 (2), pp. 177-209.

Rudra, K., 1999, The hypothesis of easterly flight of the Ganga water:
Fact or Fiction. Indian Journal of Geography and Environment, v. 4, pp. 52-55.

Rudra, K., 2014, Changing river courses in the western part of the Ganga-Brahmaputra delta. Geomorphology, v. 227, pp. 87-100. https://doi.org/10.1016/j.geomorph.2014.05.013

Sarkar, A., Sengupta, S., McArthur, J.M., Ravenscroft, P., Bera, M.K., Bhushan, R., Samanta, A. and Agrawal, S., 2009, Evolution of Ganges-Brahmaputra western delta plain: clues from sedimentology and carbon isotopes. Quaternary Science Reviews, v. 28, pp. 2564-2581.

Scherler, D., Bookhagen, B. and Strecker, M.R., 2014, Tectonic control on 10 Be-derived erosion rates in the Garhwal Himalaya, India. Journal of Geophysical Research, Earth Surface, v. 119, pp. 83-105. DOI:10.1002/2013JF002955

Sengupta, S., 1966, Geological and geophysical studies in the western part of the Bengal Basin, India. American Association of Petroleum Geology, Bulletin, v. 50 (5), pp. 1001-1017.

Seong, Y.B., Owen, L.A., Bishop, M.P., Bush, A., Clendon, P., Copland L., Finkel, R.C., Kamp, U. and Shroder, J.F., 2008, Rates of fluvial bedrock incision within an actively uplifting orogen: Central Karakoram Mountains, northern Pakistan. Geomorphology, v. 97, pp.274-286.

Sharma, S., Bartarya, S.K. and Marh, B.S., 2016, Post-glacial landform evolution in the middle Satluj River valley, India: Implications towards understanding the climate tectonic interactions. Journal of Earth System Science, v. 125, 539-558.

Shukla, U.K., 2009, Sedimentation model of gravel-dominated alluvial piedmont fan, Ganga Plain, India. International Journal of Earth Sciences, v. 98(2), pp. 443-459.

Shukla, U.K., Kotlia, B.S. and Mathur, P.D., 2002, Sedimentation pattern in a trans-Himalayan Quaternary lake at Lamayuru (Ladakh), India. Sedimentary Geology, v. 148, pp. 405-424.

Shukla, U.K., Singh, I.B., Sharma, M. and Sharma, S., 2001, A model of alluvial megafan sedimentation: Ganga Megafan. Sedimentary Geology, v. 144, pp. 243-262.

Shukla, U.K., Srivastava, P. and Singh, I.B., 2012, Migration of the Ganga River and development of cliffs in the Varanasi region, India during the late Quaternary: Role of active tectonics. Geomorphology, v. 171, pp. 101-113.

Sinclair, H.D., Mudd, S.M., Dingle, E., Hobley, D.E.J., Robinson, R. and Walcott, R., 2017, Squeezing river catchments through tectonics: Shortening and erosion across the Indus Valley, NW Himalaya. Bulletin, v. 129(1-2), pp.203-217.

Singh, A.K., Pattanaik, J.K. and Jaiswal, M.K., 2017. Late Quaternary evolution of Tista River terraces in Darjeeling-Sikkim-Tibet wedge: Implications to climate and tectonics. Quaternary International, v. 443, pp.132-142.

Singh, D.S. and Awasthi, A., 2011, Natural hazards in the Ghaghara River area, Ganga Plain, India. Natural Hazards, v. 57, pp. 213225.

Singh, D.S., 2014, Surface processes during flash floods in the glaciated terrain of Kedarnath, Garhwal Himalaya and their role in the modification of landforms. Current Science, V. 106, pp.710.

Singh, I.B., 1996, Geological Evolution of Ganga Plain- An overview. Journal of Palaeontological Society of India, v. 41, pp. 99-137.

Singh, I.B., Rajagopalan, G., Agarwal, K.K., Srivastava, P., Sharma, M. and Sharma, S., 1997, Evidence of Middle to Late Holocene neotectonic activity in the Ganga Plain. Current Science, pp. 11141117.

Singh, L.P., Parkash, B. and Singhvi, A.K., 1998, Evolution of the Lower Gangetic Plain landforms and soils in West Bengal, India. Catena, v. 33, pp. 75-104.

Singh, S. and Jain, A.K., 2007, Liquefaction and fluidization of 
lacustrine deposits from Lahaul-Spiti and Ladakh Himalaya: Geological evidences of paleoseismicity along active fault zone. Sedimentary Geology, v. 196(1-4), pp.47-57.

Singh, V. and Tandon, S.K., 2007, Evidence and consequences of tilting of two alluvial fans in the Pinjaur dun, Northwestern Himalayan Foothills. Quaternary International, v. 159(1), pp. 2131.

Singh, V. and Tandon, S.K., 2008, The Pinjaur dun (intermontane longitudinal valley) and associated active mountain fronts, NW Himalaya: Tectonic geomorphology and morphotectonic evolution. Geomorphology, v. 102(3-4), pp. 376-394.

Singh, V. and Tandon, S.K., 2010, Geomorphology Integrated analysis of structures and landforms of an intermontane longitudinal valley (Pinjaur dun) and its associated mountain fronts in the NW Himalaya. Geomorphology, v. 114, pp. 573589. DOI:10.1016/j.geomorph.2009.09.019

Sinha, R., Bapalu, G.V., Singh, L.K. and Rath, B., 2008, Flood risk analysis in the Kosi river basin, north Bihar using multi-parametric approach of analytical hierarchy process (AHP). Journal of the Indian Society of Remote Sensing, v. 36(4), pp. 335-349.

Sinha, R., Jain, V., Prasad Babu, G. and Ghosh, S., 2005, Geomorphic characterization and diversity of the fluvial systems of the Gangetic Plains. Geomorphology, v. 70(3-4), pp. 207-225.

Sinha, R., Sripriyanka, K., Jain, V. and Mukul, M., 2014, Avulsion threshold and planform dynamics of the Kosi River in north Bihar (India) and Nepal: A GIS framework. Geomorphology, v. 216, pp. 157-170.

Sinha, R. and Sarkar, S., 2009, Climate-induced variability in the Late Pleistocene-Holocene fluvial and fluvio-deltaic successions in the Ganga plains, India: A synthesis. Geomorphology, v. 113: pp. 173-188.

Sinha, R., Bhattacharjee, P.S., Sangode, S.J., Gibling, M.R., Tandon, S.K., Jain, M. and Godfrey-Smith, D., 2007, Valley and interfluve sediments in the Southern Ganga Plains, India: Exploring facies and magnetic signature. Sedimentary Geology, v. 201, pp. 386411, DOI: 10.1016/j.sedgeo .2007.07.004.

Sinha, R., Kettanah, Y., Gibling, M.R., Tandon, S.K., Jain, M., Bhattacharjee, P.S., Dasgupta, A.S. and Ghazanfari, P., 2009, Craton-derived alluvium as a major sediment source in the Himalayan Foreland Basin of India Craton-derived alluvium in Himalayan foreland basin. GSA Bulletin, v. 121(11-12), pp. 15961610.

Srivastava, P. and Misra, D.K., 2008, Morpho-sedimentary records of active tectonics at the Kameng river exit, NE Himalaya. Geomorphology, v.96, pp. 187-198. DOI:10.1016/ j.geomorph.2007.07.019

Srivastava, P. and Misra, D.K., 2012, Optically Stimulated Luminescence Chronology of Terrace Sediments of Siang River, Higher NE Himalaya: Comparison of Quartz and Feldspar Chronometers. Journal Geological Society of India, v. 79, pp. 252-258.

Srivastava, P. and Shukla, U.K., 2009, Quaternary Evolution of the Ganga River System/ : New Quartz Ages and a review of Luminescence Chronology. Himalayan Geology, v. 30, pp. 8594.

Srivastava, P., Aruche, M., Arya, A., Pal, D.K. and Singh, L.P., 2016, A micromorphological record of contemporary and relict pedogenic processes in soils of the Indo Gangetic Plains: implications for mineral weathering, provenance and climatic changes. Earth Surface Processes and Landforms, v. 41(6), pp.771-790.

Srivastava, P., Bhakuni, S.S., Luirei, K. and Misra, D.K., 2009, Morpho sedimentary records at the Brahmaputra River exit, NE Himalaya: Climate-tectonic interplay during the Late Pleistocene-
Holocene. Journal of Quaternary Science: Published for the Quaternary Research Association, v. 24(2), pp.175-188.

Srivastava, P., Kumar, A., Chaudhary, S., Meena, N., Sundriyal, Y.P., Rawat, S., Rana, N., Perumal, R.J., Bisht, P., Sharma, D., Agnihotri, R., Bagri, D.S., Juyal, N., Wasson, R.J. and Ziegler, A.D., 2017, Paleofloods records in Himalaya. Geomorphology, v. 284, pp. 17-30. DOI:10.1016/j.geomorph.2016.12.011

Srivastava, P., Pal, D.K., Aruche, K.M., Wani, S.P. and Sahrawat, K.L., 2015, Soils of the Indo-Gangetic Plains: a pedogenic response to landscape stability, climatic variability and anthropogenic activity during the Holocene. Earth-Science Reviews, v. 140, pp.54-71.

Srivastava, P., Rajak, M.K., Sinha, R., Pal, D.K. and Bhattacharyya, T., 2010, A high-resolution micromorphological record of the Late Quaternary paleosols from Ganga-Yamuna interfluve: Stratigraphic and paleoclimatic implications. Quaternary International, v. 227(2), pp.127-142.

Srivastava, P., Ray, Y., Phartiyal, B. and Sharma, A., 2013, Late Pleistocene-Holocene morphosedimentary architecture, Spiti River, arid higher Himalaya. International Journal of Earth Sciences, v. 102, pp.1967-1984.

Srivastava, P., Singh, I.B., Sharma, S., Shukla, U.K. and Singhvi, A.K., 2003b, Late Pleistocene-Holocene hydrologic changes in the interfluve areas of the central Ganga Plain, India. Geomorphology, v. 54, pp. 279-292.

Srivastava, P., Singh, I.B., Sharma, M. and Singhvi, A.K. 2003a, Luminescence chronometry and Late Quaternary geomorphic history of the Ganga Plain, India. Palaeogeography, Palaeoclimatology, Palaeoecology, v. 197, pp. 15-41.

Srivastava, P., Sinha, R., Deep, V., Singh, A. and Upreti, N., 2018, Micromorphology and sequence stratigraphy of the interfluve paleosols from the Ganga Plains: a record of alluvial cyclicity and paleoclimate during the late Quaternary. Journal of Sedimentary Research, v. 88(1), pp.105-128.

Srivastava, P., Tripathi, J.K., Islam, R. and Jaiswal, M.K., 2008, Fashion and phases of late Pleistocene aggradation and incision in the Alaknanda River Valley, western Himalaya, India. Quaternary Research, v. 70, pp. 68-80. DOI:10.1016/ j.yqres.2008.03.009

Stanley, D.J. and Hait, A.K., 2000, Holocene Depositional Patterns, Neotectonics and Sundarban Mangroves in the Western GangesBrahmaputra Delta. Journal of Coastal Research, v.16 (1), pp. 26-39.

Sundriyal, Y.P., Shukla, A.D., Rana, N., Jayangondaperumal, R., Srivastava, P., Chamyal, L.S., Sati, S.P. and Juyal, N., 2015, Terrain response to the extreme rainfall event of June 2013: Evidence from the Alaknanda and Mandakini River Valleys, Garhwal Himalaya India. Episodes, v. 38, pp.179-188.

Suresh, N., Bagati, T.N., Kumar, R. and Thakur, V.C., 2007, Evolution of Quaternary alluvial fans and terraces in the intramontane Pinjaur Dun, Sub-Himalaya, NW India/ : interaction between tectonics and climate change. Sedimentology, v. 54, pp. 809-833. DOI:10.1111/j.1365-3091.2007.00861.x

Tandon, S.K. and Singh, V., 2014, Duns: Intermontane basins in the Himalayan frontal zone. In Landscapes and Landforms of India (pp. 135-142). Springer, Dordrecht.

Tandon, S.K., Gibling, M.R., Sinha, R., Singh, V., Ghazanfari, P., Dasgupta, A.S., Jain, M. and Jain, V., 2006, Alluvial valleys of the Gangetic Plains, India: timing and causes of incision. In: Dalrymple, R.D., Leckie, D.A., Tillman, R. (Eds.), Incised Valleys in Time and Space. SEPM Special Publication, vol. 85. Tulsa, Oklahoma, USA, pp. 15-35.

Tandon, S.K., Sinha, R., Gibling, M.R., Dasgupta, A.S. and Ghazanfari, P., 2008, Late Quaternary Evolution of the Ganga 
Plains: Myths and Misconceptions, Recent Developments and Future Directions. Memoir Journal Geological Society of India, v. 66, pp. 259-299.

Thakur, V.C., 2013, Active tectonics of Himalayan Frontal Fault system. International Journal of Earth Sciences, v. 102(7), pp. 1791-1810. DOI:10.1007/s00531-013-0891-7

Thakur, V.C., Pandey, A.K. and Suresh, N., 2007, Late Quaternary Holocene evolution of Dun structure and the Himalayan Frontal Fault zone of the Garhwal. Journal of Asian Earth Science, v. 29, pp. 305-319. DOI:10.1016/j.jseaes.2006.02.002

Tewari, R., Pant, P.C., Singh, I.B., Sharma, S., Sharma, M., Srivastava, P., Singhvi, A.K., Mishra, P.K. and Tobschall, H.J., 2002, Middle Palaeolithic human activity and palaeoclimate at Kalpi in Yamuna valley, Ganga plain. Man and Environment, v. 27(2), pp. 1-13.

Tripathi, J.K., Bock, B. and Rajamani, V., 2013, Nd and Sr isotope characteristics of Quaternary Indo-Gangetic plain sediments: Source distinctiveness in different geographic regions and its geological significance. Chemical Geology, v. 344, pp. 12-22.

Vaidyanadhan R. and Ghosh R.N., 1993, Quaternary of the East Coast of India. Current Science, v. 64, pp. 804-815.

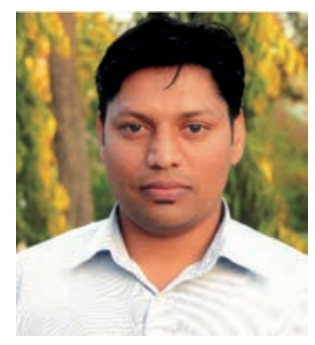

Anil Kumar is Scientist at Wadia Institute of Himalaya Geology, Dehradun. He worked on Quaternary landscape evolution along the Indus and Zanskar rivers and paleoflood records from Indus and Brahmaputra rivers. His broad area of research is climate-tectonic interaction and landform evolution. He also has worked on sand ramps in the Ladakh Himalaya. He participated in International Ocean Discovery Program (IODP) Expedition 355 in 2015 and understand the sedimentation and their source based on grain size and environmental magnetic parameters in Arabian Sea.

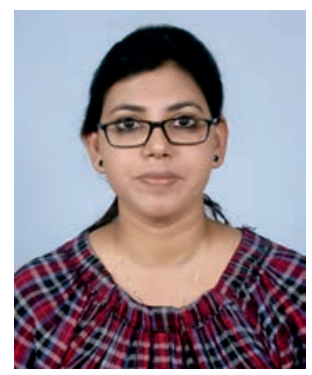

Rupa Ghosh is currently working as a Research Associate at Birbal Sahni Institute of Palaeosciences, Lucknow. She completed her PhD thesis from Wadia Institute of Himalayan Geology, Dehradun and Banaras Hindu University in2018. Her PhD thesis demonstrate Himalayan fore-bulge dynamics, sediment yield of ravine erosion and past $100 \mathrm{ka}$ sedimentation history in Marginal Ganga Foreland. Her research focuses on Late Quaternary fluvial deposits and related landform evolution with a combination of sedimentological and geomorphological modeling, optical stimulated luminescence geochronology.
Verma, B.C., Mishra, V.P., Mishra, A. and Kumar, U., 1998, Discovery of Early Quaternary vertebrate fossils beneath the Ganga river bed at Bhagalpur, Bihar: their age and biostratigraphic implications. Journal of Palaeontological Society of India, v. 43, pp.35-40.

Wasson, R.J., Chauhan, M.S., Sharma, C., Jaiswal, M., Singhvi, A.K. and Srivastava, P., 2013, Erosion of river terraces as a component of large catchment sediment budgets: A pilot study from the Gangetic Plain. Journal of Asian Earth Sciences, v. 67, pp. 1825.

Wesnousky, S.G., Senthil Kumar, B., Mohindra, R. and Thakur, V.C., 1999, Uplift and convergence along the Himalayan Frontal Thrust of India. Tectonics, v.18, pp. 967-976.

Wilson, C.A. and Goodbred Jr., S.L., 2015, Construction and Maintenance of the Ganges-Brahmaputra-Meghna Delta: Linking Process, Morphology, and Stratigraphy. Annual Review of Marine Science, v. 7, pp. 17.1-17.22.

Yin, A. and Harrison, T.M., 2000, Geologic evolution of the Himalayan-Tibetan Orogen. Annual Review of Earth and Planetary Sciences, v. 28, pp. 211-280.

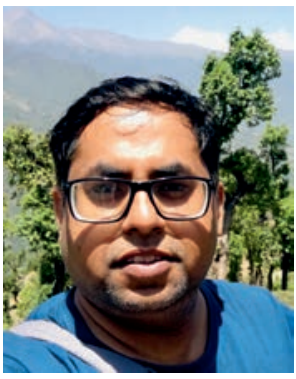

Vimal Singh is Assistant Professor at the University of Delhi. He did his M.Sc from Banaras Hindu University and Ph.D from University of Delhi. His broad area of research is Tectonic Geomorphology. His current research work is focused on studying the response of Himalayan rivers to tectonic and climatic changes during Late Pleistocene. 